\title{
LINGKUNGAN PENGENDAPAN DI SITUS NEGERI BARU, KALIMANTAN BARAT
}

\author{
Yuka Nurtanti Cahyaningtyas*
}

\author{
Balai Arkeologi Banjarmasin, Jalan Gotong Royong II, RT 03/06, Banjarbaru 70711, Kalimantan Selatan; \\ Telepon (0511) 4781716; Facsimile (0511) 4781716
}

Artikel masuk pada 12 Desember 2012

Artikel selesai disunting pada 26 Maret 2013

\begin{abstract}
Abstrak. Situs Negeri Baru terletak di tepi aliran Sungai Pawan yang bermuara di Selat Karimata. Satuan batuan di Situs Negeri Baru adalah aluvium dan endapan rawa, yang terdiri atas lingkungan pengendapan aluvium resen, aluvium tua, dan endapan rawa dataran pantai. Tulisan ini membahas lebih jauh karakteristik lingkungan pengendapan di kawasan Situs Negeri Baru. Studi ini dilakukan dengan analisis sedimentologi dan stratigrafi berdasarkan data dari delapan belas kotak ekskavasi. Hasil kajian menunjukkan bahwa korelasi perubahan lingkungan pengendapan secara lateral dan vertikal pada rangkaian endapan kuarter di Situs Negeri Baru diindikasikan merupakan perubahan dari lingkungan permukaan pantai atas (upper shoreface) menjadi sol. Lingkungan pengendapan ini terletak pada estuari dan permukaan pantai (shoreface) dan sangat dipengaruhi oleh pasang surutnya air laut.
\end{abstract}

Kata kunci: endapan aluvium, endapan rawa, permukaan pantai, estuari, pasang surut, perubahan lingkungan pengendapan

\begin{abstract}
THE CHARACTERISTIC OF DEPOSITIONAL ENVIRONMENT OF NEGERI BARU, WEST KALIMANTAN. Negeri Baru lies on the bank of Pawan River which empties into the Karimata Strait. The lithology of Negeri Baru comprise of alluvium and marsh sediment, which consists of the deposition of recent alluvium, old alluvium, and coastal marsh sediments. This paper further discusses the characteristics of the depositional environment in the region of Negeri Baru. This study was conducted with the sedimentology and stratigraphical analysis based on data unearthed from eighteen excavation pits. The result showed that the correlation of changes of depositional environment between lateral and vertical Quarter sediment series in Negeri Baru is indicated by the change from upper 'shoreface' to sol. Such depositional environment is located on the estuary and 'shoreface', which is strongly influenced by ocean tides.
\end{abstract}

Keywords: alluvium sediment, marsh sediments, 'shoreface', estuary, tidal, changes of depositional environment

* Penulis adalah asisten peneliti pada Balai Arkeologi Banjarmasin, email: yuka.nurtanti@gmail.com 


\section{A. Pendahuluan}

1. Latar Belakang

Situs Negeri Baru terletak kurang lebih 20 $\mathrm{km}$ dari Kota Ketapang. Pada waktu ditemukan, Situs Negeri Baru merupakan tumpukan batu bata yang digunakan penduduk sebagai bahan bangunan yang digunakan sendiri, bahkan diperdagangkan (Tim Penelitian 2010). Penelitian yang telah dilaksanakan pada 2007 dan 2010 memperkirakan bahwa kemungkinan tumpukan batu bata ini merupakan sebuah bangunan candi. Situs Negeri Baru ini berada di tepi Sungai Pawan yang memiliki bentang alam dataran pantai aluvium dan litoral tersusun oleh endapan aluvium dan rawa. Sungai Pawan merupakan sungai terbesar di daerah Ketapang yang mengalir ke arah Selat Karimata. Pada saat ini, Sungai Pawan sudah mempunyai lembah berbentuk $U$ dan bentuk sungainya apabila dilihat dalam peta maupun dari atas nampak berkelok-kelok (meandering) yang menandakan bahwa sungai tersebut sudah berada pada stadium tua. Faktor ini yang memberikan asumsi bahwa Sungai Pawan sudah mengalami perpindahan aliran sungai beberapa kali. Dalam Keyser dan Rustandi (1993) dijelaskan bahwa bentang alam di Ketapang, Kalimantan Barat merupakan suatu peneplain.

Situs Negeri Baru merupakan temuan yang sangat penting dalam ranah arkeologi Indonesia. Oleh karena itu, perlu diketahui lingkungan pengendapan pada saat situs tersebut dibangun. Informasi dasar geologi, khususnya endapan Kuarter secara detail di Desa Negeri Baru ini belum tersedia. Dengan mempelajari endapan Kuarter tersebut dapat dipergunakan untuk mengetahui perkembangan alur sungai purba dan berubahnya lingkungan terutama dataran banjir dan dataran aluvium. Penelitian ini bertujuan untuk mengetahui kondisi lingkungan pada saat bangunan tersebut dibangun serta mendeskripsikan fasies endapan Kuarter dan mempelajari hubungan fasies endapannya secara lateral dan vertikal.

Secara administratif, daerah penelitian terletak di Desa Negeri Baru, Kecamatan Benua Kayong, Kabupaten Ketapang, Kalimantan Barat (Tim Penelitian 2010). Desa Negeri Baru terletak di tepi aliran Sungai Pawan yang mengalir ke arah Selat Karimata (Gambar 1). Secara astronomis, Situs Negeri Baru berada pada koordinat titik ikat 0 , yaitu $01^{\circ} 50^{\prime} 39,9^{\prime \prime}$ LS dan $110^{\circ} 00^{\prime} 34,8^{\prime \prime}$ BT (Gambar 2).

\section{Kerangka Pikir}

Dalam Buatois dkk (1999) dijelaskan bahwa pada lingkungan pengendapan estuari dan permukaan pantai (shoreface) terdapat 15 fasies di dalamnya. Pada gambar 3 diperlihatkan tempat di mana fasies tersebut berada. Pada skema 1 dijelaskan hubungan antara fasies, proses pengendapan, dan lingkungan pengendapannya. Berikut akan diterangkan secara lengkap fasies A sampai dengan fasies 0 .

Fasies A merupakan fasies batupasir berukuran halus dengan proses pengendapannya tractive current dan fasies ini terdapat pada lingkungan pengendapan alur sungai (fluvial channel). Dilanjutkan dengan fasies $B$, yang merupakan fasies batulanau berakar dengan proses pengendapannya proses pedogenik. Fasies $B$ ini terdapat pada lingkungan pengendapan tanah purba (paleosol). Setelah itu adalah fasies $C$, yaitu batupasir halus sampai sangat kasar bersisipan lempung (very coarse grained to fine-grained sandstones with clay drapes) 


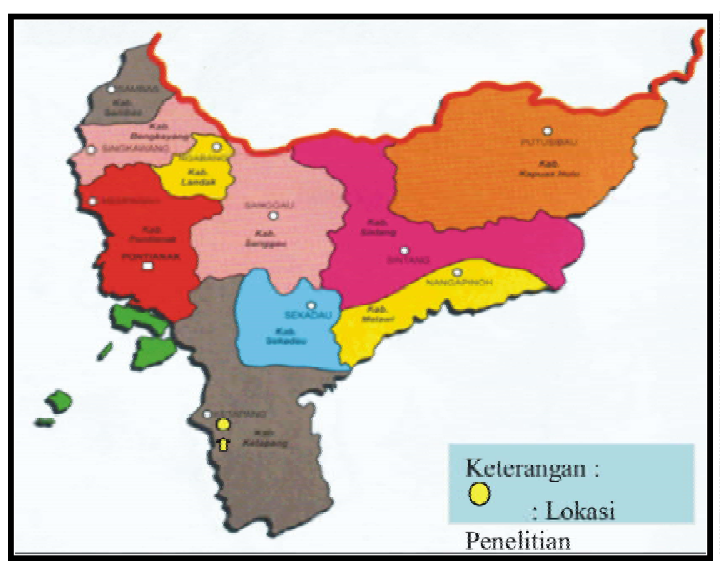

Gambar 1. Peta Lokasi Situs Negeri Baru (Indonesia Kalimantan Barat, 2010)

dengan proses pengendapannya migration of subaqueous, unidirectional flow dunes, dan slack-water sediment fallout pada lingkungan pengendapan upper-estuarine, bay-head delta channels. Sementara itu, fasies $D$ adalah napal hitam berlaminasi sejajar dengan fading ripples (parallel-laminated black shales with fading ripples). Proses pengendapannya yaitu sediment fallout and low-energy tidal currents dan lingkungan pengendapan adalah teluk bagian tengah estuari (central-estuarine bay). Sedangkan fasies $E$ adalah batupasir dan batulanau dengan perlapisan flaser dan wavy (flaser and wavy-bedded sandstones and siltstones) dengan proses pengendapannya arus pasang surut dan lingkungan pengendapannya dataran pasang surut yang terbatas (restricted tidal flat).

Fasies $\mathrm{F}$ berupa batupasir dan batulanau yang terdeformasi naik (inclined, deformed sandstones, dan siltstones) dengan proses pengendapannya melalui arus pasang surut (tidal currents), sediment downslope movement dan lateral accretion. Lingkungan pengendapannya terletak pada alur pasang surut (tidal channel). Fasies $\mathrm{G}$ yaitu laminated calcareous mudstones dengan proses pengendapan sediment fallout dan lingkungan pengendapan estuari bawah.

Fasies $\mathrm{H}$ berupa poorly to moderately fossiliferous, planar-crossbedded sandstones dengan proses pengendapan migration of subaqueous, unidirectional flow dunes, dan lingkungan pengendapannya adalah mulut estuari. Fasies I berupa highly fossiliferous, planar-crossbedded, very coarse grained to medium-grained sandstones, dan pebble conglomerates dengan proses pengendapan berupa migration of subaqueous, unidirectional flow dunes dan lingkungan pengendapan permukaan pantai atas (upper shoreface). Fasies J yaitu rarely to moderately burrowed, planar-crossbedded, medium- to fine-grained sandstones dengan proses pengendapan migration of subaqueous, unidirectional flow dunes dan lingkungan pengendapan proximal middle shoreface.

Fasies $\mathrm{K}$ merupakan moderately to thoroughly burrowed, rippled, fine-grained sandstones dengan proses pengendapan 


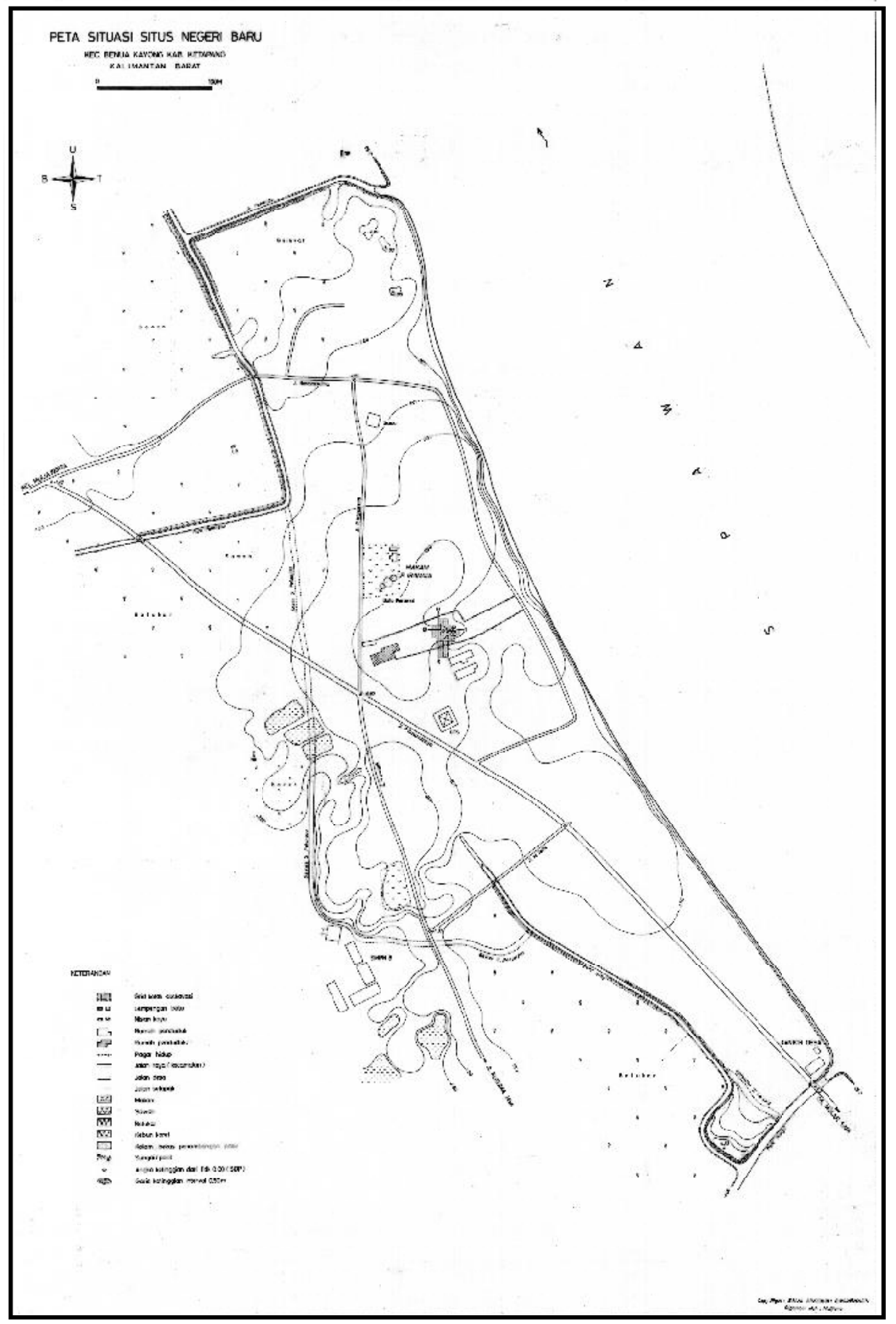

Gambar 2. Peta Situasi Situs Negeri Baru (dok. Balai Arkeologi Banjarmasin, 2010) 
migration of subaqueous, unidirectional flow ripples dan sediment fallout dan lingkungan pengendapan distal middle shoreface. Fasies $\mathrm{L}$ yaitu thoroughly burrowed, fine-grained to very fine grained silty sandstones with starved ripples dengan proses pengendapan migration of subaqueous, unidirectional flow ripples and sediment fallout dan lingkungan pengendapan lower shoreface. Fasies M berupa thoroughly burrowed, very fine grained silty sandstones dan siltstones with interbedded, normally graded sandstones dengan proses pengendapan storm action dan sediment fallout dan lingkungan pengendapan transisi lepas pantai (offshore transition). Fasies $\mathrm{N}$ merupakan thoroughly burrowed siltstones dengan proses pengendapan sediment fallout dan lingkungan pengendapannya lepas pantai. Fasies 0 merupakan parallel laminated black shales dengan proses pengendapan sediment fallout dan lingkungan pengendapannya paparan (shelf).

Skema 1. Fasies dan Lingkungan Pengendapan dari Batupasir Morrow bawah di lapangan Arroyo dan Gentzler (Buatois dkk, 1999).

\begin{tabular}{|c|c|c|}
\hline Facies & Depositional Process & $\begin{array}{l}\text { Sedimentary } \\
\text { Environment }\end{array}$ \\
\hline A: Fine-grained sandstones & Tractive currents & Fluvial channels \\
\hline B: Rooted siltstones & Pedogenic processes & Paleosol \\
\hline $\begin{array}{l}\text { C: Very coarse grained to fine-grained sandstones with } \\
\text { day drapes }\end{array}$ & $\begin{array}{l}\text { Migration of subaqueous, unidirectional } \\
\text { flow dunes and slack-waler sediment } \\
\text { fallout }\end{array}$ & $\begin{array}{l}\text { Upper-estuarine, bay- } \\
\text { head delta channels }\end{array}$ \\
\hline D: Parallel-Jaminated black shales with fading ripples & $\begin{array}{l}\text { Sediment fallout and low-energy tidal } \\
\text { currents }\end{array}$ & Central-estuarine bay \\
\hline E: flaser- and wavy-bedded sandstones and siltstones & Tidal currents & Restricted tidal flat \\
\hline F: Inclined, deformed sandstones and siltstones & $\begin{array}{l}\text { Tidal currents, sediment downslope } \\
\text { movement and lateral accretion }\end{array}$ & Tidal channel \\
\hline G: Laminated calcareous mudstones & Sediment fallout & Lower estuary \\
\hline $\begin{array}{l}\text { H: Poorly to moderately fossiliferous, planar- } \\
\text { crossbedded sandstones }\end{array}$ & $\begin{array}{l}\text { Migration of subaqueous, unidirectional } \\
\text { flow dunes }\end{array}$ & Estuarine mouth \\
\hline $\begin{array}{l}\text { 1: Highly fossiliferous, planar-crossbedded, very coarse } \\
\text { grained to medium-grained sandstones and pebble } \\
\text { conglomerates }\end{array}$ & $\begin{array}{l}\text { Migration of subaqueous, unidirectional } \\
\text { flow dunes }\end{array}$ & Upper shoreface \\
\hline $\begin{array}{l}\text { J: Rarely to moderately burrowed, plana-crossbedded, } \\
\text { medium- to fine-grained sandstones }\end{array}$ & $\begin{array}{l}\text { Migration of subaqueous, unidirectional } \\
\text { flow dunes }\end{array}$ & $\begin{array}{l}\text { Proximal middle } \\
\text { shoreface }\end{array}$ \\
\hline $\begin{array}{l}\text { K: Moderately to thoroughly burrowed, rippled, fine- } \\
\text { grained sandstones }\end{array}$ & $\begin{array}{l}\text { Migration of subaqueous, unidirectional } \\
\text { flow ripples and sediment fallout }\end{array}$ & Distal middle shoreface \\
\hline $\begin{array}{l}\text { L: Thoroughly burrowed, fine grained to very fine } \\
\text { grained silty sandstones with starved ripples }\end{array}$ & $\begin{array}{l}\text { Migration of subaqueous, unidirectional } \\
\text { flow ripples and sediment fallout }\end{array}$ & Lower shoreface \\
\hline $\begin{array}{l}\text { M: Thoroughly burrowed, very fine grained silty } \\
\text { sandstones and siltstones with interbedded, normally } \\
\text { graded sandstones }\end{array}$ & Storm action and sediment fallout & Offshore transition \\
\hline $\mathrm{N}$ : Thoroughly burrowed siltstones & Sediment fallout & Offshore \\
\hline 0:Parallel laminated black shales & Sediment fallout & Shelf \\
\hline
\end{tabular}




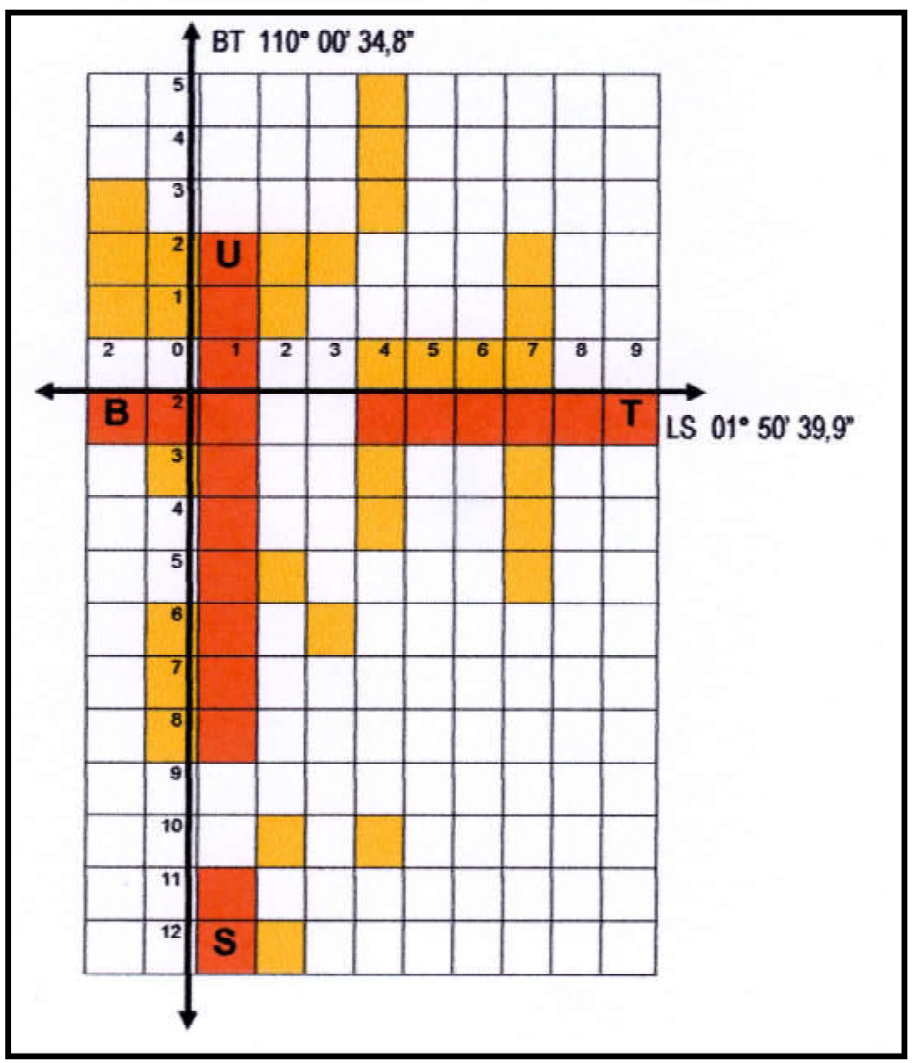

Gambar 4. Grid lokasi kotak ekskavasi Situs Negeri Baru (dok. Balai Arkeologi Banjarmasin)

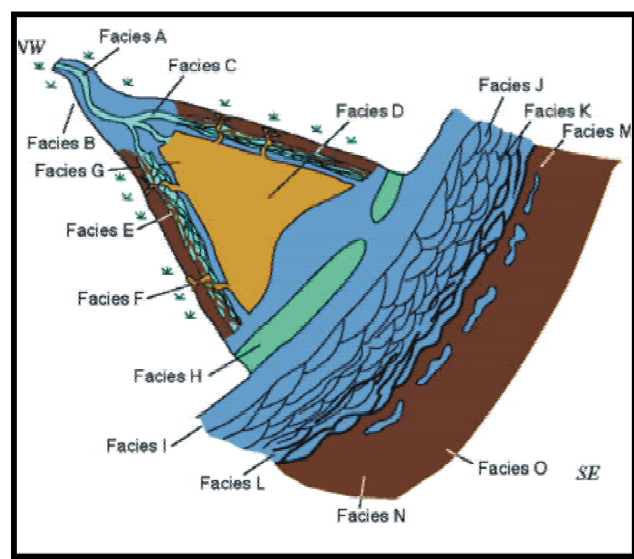

Gambar 3. Model lingkungan pengendapan pada Batupasir Morrow bawah di lapangan Arroyo dan Gentzler (Buatois dkk, 1999)

\section{Metode Penelitian}

Penelitian ini dilakukan dengan menggunakan metode ekskavasi atau penggalian arkeologi dalam pengambilan datanya. Endapan di daerah penelitian telah diamati pada sejumlah kotak ekskavasi dengan berbagai ukuran antara lain $1 \times 1 \mathrm{~m}$, $2 \times 1 \mathrm{~m}, 3 \times 1 \mathrm{~m}$, dan $4 \times 1 \mathrm{~m}$. Selanjutnya, dipelajari pembentukan dan pengembangan fasiesnya. Metode ekskavasi pada penelitian ini menggunakan teknik gabungan atau perpaduan antara metode grid dengan metode trench. Hal ini disesuaikan dengan tujuan untuk menampakkan denah, struktur, 
dan bentuk bangunan. Pada umumnya, kotak ekskavasi dibuat dalam grid dengan ukuran $2 \times 2 \mathrm{~m}$, namun pembukaan kotak disesuaikan dengan keperluan penelitian. Kotak ekskavasi yang dipelajari dengan detail adalah sebagai berikut: satu lintasan berorientasi utaraselatan (U-S) berisi 10 kotak ekskavasi (S2B2S2T9) dan satu lintasan berorientasi barattimur (B-T) berisi 8 kotak ekskavasi (U2T1S12T1) (Gambar 4).

Lintasan ekskavasi tersebut kemudian digunakan untuk mempelajari stratigrafi endapan yang tersingkap di dinding kotak. Stratigrafi kotak-kotak ekskavasi ini kemudian dibuatkan penampang stratigrafinya. Pembuatan penampang stratigrafi pada kotak gali ini mengadopsi "Sistem Legenda Tipe Penampang" (Profile-Type-Legend System) yang umum dipakai dalam penelitian/ pemetaan geologi Kuarter berdasarkan data pemboran tangan. "Sistem Legenda Tipe Penampang" ini memunculkan unit-unit peta yang diwakili oleh tipe penampang (uruturutan vertikal dari endapan sedimen sampai kedalaman tertentu) (Moechtar 2007). Endapan ini selanjutnya diplot dan dideskripsikan ke dalam penampang vertikal sedimen dalam skala tertentu dengan kedalaman kurang lebih $1 \mathrm{~m}$.

Delapan belas kotak ekskavasi yang berarah utara-selatan dan barat-timur selanjutnya dikorelasikan satu sama lain. Rangkaian stratigrafi ini dipelajari untuk mengetahui pembentukan dan perkembangan fasiesnya, baik vertikal maupun lateral. Selain data dari kotak gali, peneliti juga mengumpulkan data dari peneliti terdahulu serta melakukan pengamatan geologi di sekitar lokasi penggalian serta di lokasi sekitar Situs Negeri Baru tersebut berada.

\section{B. Geologi Umum}

Geologi umum meliputi satuan bentang lahan/geomorfologi/fisiografi, struktur geologi serta stratigrafi umum daerah penelitian.

\section{Fisiografi}

Sebagian besar wilayah Ketapang merupakan suatu peneplain ke arah timur yang berangsur menjadi bentang alam bergelombang (de Keyser dan Rustandi 1993). Bentang alam bergelombang ini terdiri atas perbukitan dan lebih jauh ke arah timur merupakan tanah tinggi pegunungan. Oleh karena itu, bentang alam di wilayah Ketapang dapat dibedakan menjadi dataran pantai aluvium dan litoral, tanah rendah bergelombang, dan tanah tinggi pegunungan.

Dataran pantai aluvium dan litoral merupakan wilayah datar yang kurang aliran sungai dan pada umumnya berawa. Wilayah ini meliputi luas $3750 \mathrm{~km}^{2}$ atau $27 \%$ dari daratan Ketapang yang memiliki luas 13.500 $\mathrm{km}^{2}$. Dataran ini lebar, merentang dari pantai ke pedalaman sampai sejauh $70 \mathrm{~km}$. Wilayah ini dicirikan oleh sungai meander dengan potongan-potongan meander dan danau "oxbow" dan beberapa bentukan geologi batuan "keras", yaitu singkapan granit dan batuan gunung api yang terasing. Tumbuhan mangrove atau bakau umum terdapat sepanjang jalur sungai dan pesisir.

Tanah rendah bergelombang diperlihatkan pada kawasan dataran rendah dengan perbukitan yang rapat dan terpotongpotong, yang terdiri atas bukit-bukit membulat dan peneplain yang tertoreh. Reliefnya rendah dengan ketinggian umumnya kurang dari 500 
$\mathrm{m}$, tetapi terdapat bukit-bukit dengan puncak sampai dengan $600 \mathrm{~m}$ secara setempat terdapat di bagian barat dan di bagian timur mencapai ketinggian $800 \mathrm{~m}$. Pola pengaliran umumnya dendritik dengan beberapa sungai besar diapit oleh dataran banjir dan rawarawa. Akibat tingkat kedewasaan bentang alam yang terlalu lanjut dan rapatnya tumbuhtumbuhan, maka alur-alur sungai kecil sulit dilacak.

Tanah tinggi pegunungan dicirikan oleh lereng yang terjal, relief tinggi, topografi "muda", lembah berbentuk ' $\mathrm{V}$ ', dan erosi yang kuat. Dataran tinggi ini bertepatan dengan bagian batas antara Kalimantan Barat dan Kalimantan Tengah, membentuk penonjolan dengan bentang alam pegunungan di mana puncak-puncaknya mencapai ketinggian lebih dari $800 \mathrm{~m}$ di timur laut dan tenggara Ketapang. Kedua penonjolan ini dipisahkan oleh Sungai Biya dan anak-anak sungainya, yang memotong lembah yang lebar dan umumnya melalui batuan gunungapi.

\section{Stratigrafi}

Stratigrafi daerah Ketapang seperti disebutkan dalam de Keyser dan Rustandi (1993) terdiri atas Batuan Malihan Pinoh, Komplek Ketapang, Granit Belaban, Granit Laur, Granit Sukadana, Granit Sangiyang, Retas dan sil mafik dan felsik, Batuan Gunungapi Kerabai, Basal Bunga, Batuan Terobosan Sintang, Talus serta Endapan aluvium dan endapan rawa. Alas dari Ketapang adalah batuan granit serta batuan gunungapi yang tersebar dan terpisah-pisahkan oleh singkapan batuan sedimen pra-Tersier dan sedikit batuan malihan dalam.

Batuan Malihan Pinoh terdiri atas kuarsit kelabu tua terhablur ulang mengandung anortit kaya akan turmalin, gnes klinopiroksen- hornblende mengandung klinozoisit dan skapolit, dan batuan migmatik (hulu Sungai Jelai); sekis mika dan kuarsit mika dengan biotit porfiroblastik, andalusit, dan garnet, dan muskovit sekunder dan turmalin lokal (Rantaupanjang); dan menurut van Bemmelen (1939), sekis andalusit-mika (sebelah timur laut Pehibingan) (de Keyser dan Rustandi 1993).

Komplek Ketapang terdiri atas batuan psamit dan berlapis secara pelitik, berlapis sedang sampai tipis, terubah secara beraneka ragam oleh malihan termal dan ubahan hidrotermal: batulempung, batupasir halus sampai kasar yang lempungan dan serisitan (setempat-setempat lanauan dan bersilang siur), arenit litik (beberapa tufaan atau mengandung pecahan batuan gunungapi yang "rework"), serpih (setempat-setempat pasiran), dan batusabak; jarang bagianbagian yang dolomitan atau gampingan terlestarikan sebagai batuan kalk-silikat. Batuan terangkat dan terlipat, umumnya dengan kemiringan antara $30^{\circ}$ sampai hampir tegak.

Granit Belaban terdiri atas monzonit dan monzodiorit kuarsa-hornblende(-biotit) kelabu tua, senolit yang membulat biasa terdapat, kemungkinan berasal dari batuan sedimen. Granit Laur terdiri atas monzogranit biotithornblende, sedikit syenogranit biotit dan granodiorit hornblende-biotit. Dengan litologinya yang mirip dengan litologi Granit Sukadan, Granit Laur ini mungkin lebih tersebar luas di Ketapang daripada yang terpetakan. Granit Sukadana terdiri atas batuan yang mempunyai banyak jenis/ tingkatan, yaitu monzonit kuarsa, monzogranit, syenogranit, dan granit alkali-feldspar; sedikit sienit kuarsa, monzodiorit kuarsa, diorit kuarsa, dan syenogranit; langka diorit, dan gabro. 
Granit Sangiyang terdiri atas granit feldspar alkali-pertitik granofirik leukokratik berbutir halus, dengan tekstur alotriomorfik di Bukit Sangiyang (satu-satunya singkapan dari satuan ini yang dipetakan di lapangan).

Retas dan sil mafik dan felsik, umumnya bersifat basa sampai sedang (intermedier): basal (atau dolerit) dan andesit profir; trakhit, trakhiandesit, diorit, monzonit, dan setempatsetempat riolit merupakan hal yang biasa terdapat. Basal, dolerit: hitam atau hijau tua; dicirikan oleh tekstur ofiotik atau subofiotik, dan oleh kehadiran augit bertitan, yang dapat membedakan batuan ini daripada aliran.

Batuan Gunungapi Kerabai, umumnya andesit dan basal; dolerit, trakhiandesit, keratofir kuarsa, dasit, riodasit dan riolit umum terdapat setempat-setempat; kebanyakan batuan piroklastik (abu, lapili, kristal, tufa kristal dan litik; breksi gunungapi; dan aglomerat); sedikit terobosan padan dan lava porfiritik; umumnya pecah-pecah, terubah secara hidrotermal, dan terpotong oleh urat-urat khlorit-epidot. Tufa hijau sampai kelabu, umumnya lapuk memberikan macammacam warna, coklat, merah, dan kuning; pofiroklas daripada felspar yang tersausuritisasi, hornblende, augit, sedikit kuarsa, hipersten dan biotit, sedikit olivin, fragmen batuan daripada batuan gunungapi berbutir halus.

Basal Bunga terdiri atas basal hitam sampai kelabu tua yang pejal, dengan anggota dasit dan andesit kelabu kehijauan; lava, tufa litik-kristal (setempat-setempat dengan tambahan lapili), dan breksi gunungapi; batupasir sedang sampai halus pada alasnya, menindih Batuan Gunungapi Kerabai di sebelah tenggara Bukit Bunga.
Batuan Terobosan Sintang terdiri atas tufa riodasit kaca atau terlas bersusunan pecahan batuan gunungapi yang sangat halus sampai seperti kaca, berlapisan seperti aliran, terbreksikan, dan pecahan kuarsa, plagioklas, biotit coklat, dan sedikit hornblende hijau. Talus terdiri atas rombakan kerakal dan bongkah yang kasar. Endapan aluvium dan endapan rawa terdiri atas kerikil, pasir, lanau, lumpur, gambut, dan bongkah yang tak terpisahkan.

\section{Kondisi Geologi Situs Negeri Baru}

Hasil penelitian ini merupakan data yang didapatkan dari hasil survei di sekitar lokasi situs dan data dari kotak ekskavasi di Situs Negeri Baru. Data ini kemudian dikorelasikan dengan data dari penelitian terdahulu maupun dari studi pustaka.

1. Gambaran Umum Daerah Penelitian

Gambaran umum daerah penelitian ini meliputi fisiografi dan stratigrafi di daerah sekitar Situs Negeri Baru.

\section{a. Fisiografi Daerah Penelitian}

Lokasi penelitian atau lokasi situs terletak di tepi Sungai Pawan kurang lebih $20 \mathrm{~km}$ ke arah timur dari Kota Ketapang, Kalimantan Barat. Lokasi ini berjarak kurang lebih $100 \mathrm{~m}$ dari bagian barat tepian Sungai Pawan. Rentangan angka ketinggian tempat di lokasi penelitian berkisar dari $0 \mathrm{~m}$ hingga $2,5 \mathrm{~m}$ di atas permukaan air Sungai Pawan.

Di lokasi ini hanya terdapat satu macam bentang alam atau bentuk lahan, yaitu dataran banjir yang berasal dari bentukan asal fluvial. Topografi bentuk lahan di lokasi penelitian ini termasuk datar karena hanya memiliki 
kemiringan lereng $0^{\circ}$ hingga $0,5^{\circ}$. Proses yang dominan pada bentuk lahan seperti ini adalah sedimentasi atau pengendapan. Bentuk lahan ini jika dibandingkan dengan bentang alam yang dijelaskan oleh de Keyser dan Rustandi (1993), maka bentuk lahan di lokasi penelitian termasuk dalam dataran aluvium pantai dan litoral.

\section{b. Stratigrafi Daerah Penelitian}

Stratigrafi di Situs Negeri Baru ini diamati berdasarkan stratigrafi kotak ekskavasi yang dibuat di lokasi penelitian. Penampang stratigrafi dibuat dari kotak pada lintasan S2B2 - S2T9 yang berarah barat - timur dan lintasan U2T1 - S12T1 yang berarah utara - selatan. Kotak yang digunakan pada lintasan barat timur (Gambar 5) meliputi 8 (delapan) kotak ekskavasi yang berukuran $2 \times 2 \mathrm{~m}$, namun tidak semua kotak dibuka dengan ukuran $2 \times 2 \mathrm{~m}$, beberapa kotak dibuka dengan ukuran $2 \times 1$ $m$. Delapan kotak tersebut antara lain kotak S2B2, S2B1, S2T4, S2T5, S2T6, S2T7, S2T8, dan S2T9.

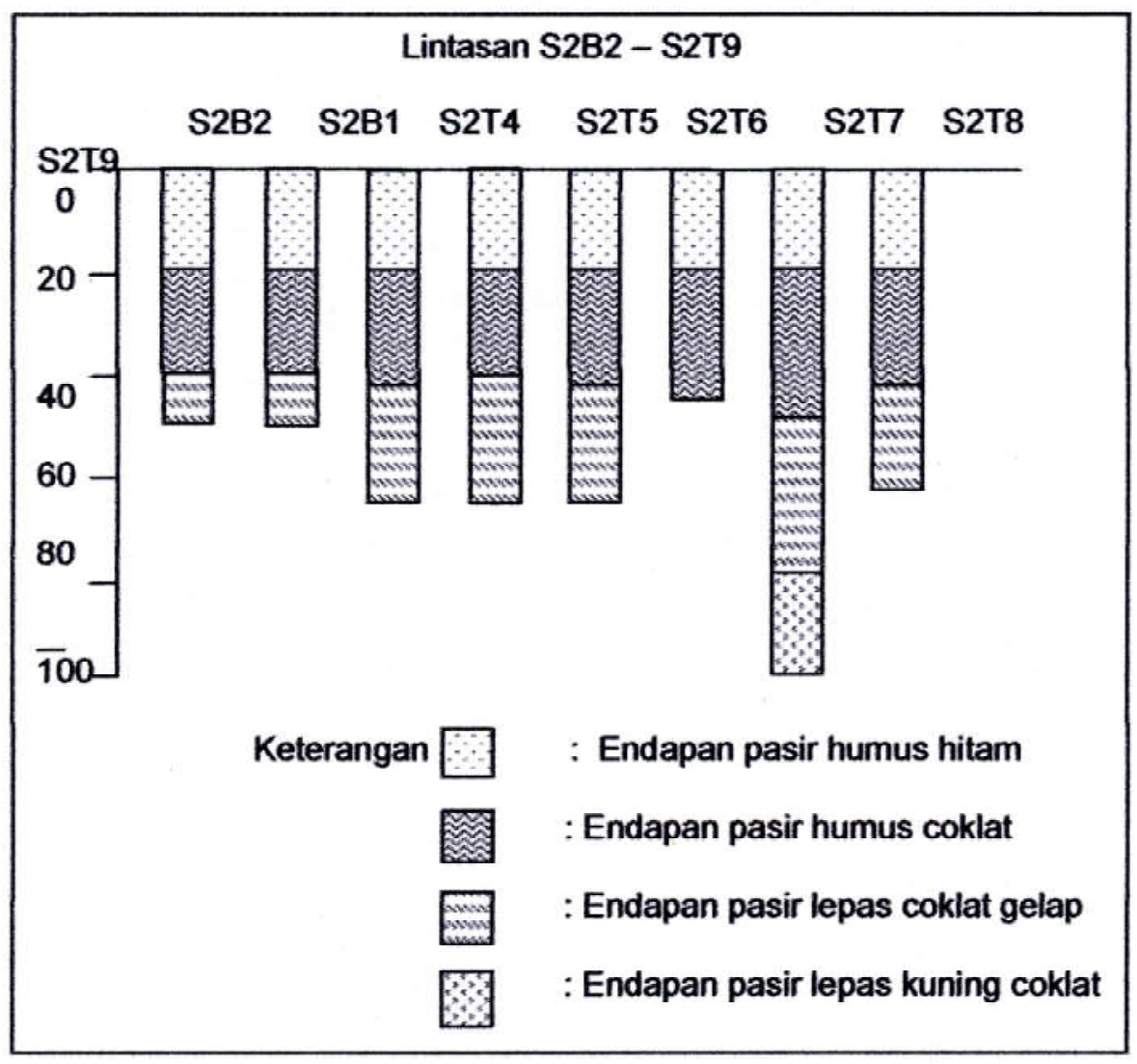

Gambar 5. Skema stratigrafi lintasan S2B2 - S2T9 


\section{Analisis Stratigrafi pada Kotak Ekskavasi}

Kotak S2B2 dan S2B1 dibuka dengan kedalaman kurang lebih $50 \mathrm{~cm}$. Stratigrafi pada kedua kotak ini memiliki dua lapisan endapan yang dapat dilihat dari dinding kotak tersebut. Kedua lapisan endapan itu adalah endapan pasir humus hitam dengan ketebalan $25 \mathrm{~cm}$ yang merupakan lapisan endapan pertama yang berada di atas dengan deskripsi sebagai berikut, endapan berupa tanah yang berwarna hitam, berukuran pasir kasar sampai dengan sedang, sedikit pasir halus dengan sortasi sedang dan endapan bersifat lepas-lepas, tidak menyatu. Lapisan endapan kedua merupakan endapan pasir humus coklat dengan ketebalan $25 \mathrm{~cm}$ berwarna coklat hitam kemerahan karena sudah bercampur dengan pecahan batu bata, berukuran butir pasir halus sampai pasir kasar.

Pada kotak S2T4, S2T5, dan S2T6 memiliki kedalaman masing-masing $60 \mathrm{~cm}$. Stratigrafi yang terdapat pada ketiga kotak tersebut adalah lapisan endapan pasir humus hitam, endapan pasir humus coklat, dan endapan pasir lepas coklat gelap. Lapisan endapan pasir humus hitam memiliki ukuran butir pasir kasar sampai dengan lanau.

Kotak S2T7 yang memiliki kedalaman $40 \mathrm{~cm}$ ini dibuka dengan tujuan untuk mengetahui kelanjutan struktur batu bata yang ditemukan di kotak S2T5. Stratigrafi yang terdapat pada kotak ini adalah lapisan endapan pasir humus hitam dan endapan pasir humus coklat dengan deskripsi berwarna berwarna Hue 2,5 Y 3/3 (dark olive

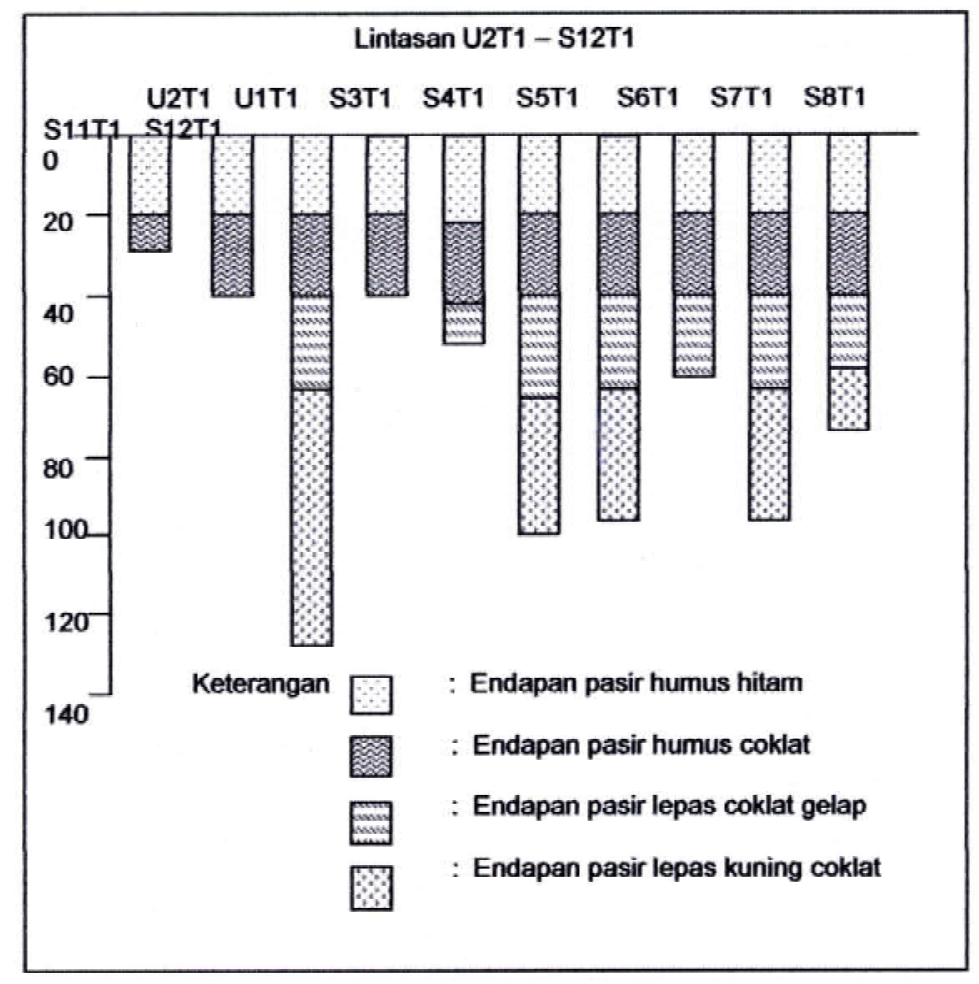

Gambar 6. Skema stratigrafi lintasan U2T1 - S12T1 
brown) dengan ukuran butir pasir kasar sedang, dan tidak kompak.

Kotak S2T8 dibuka sampai dengan kedalaman $100 \mathrm{~cm}$ dan kotak S2T9 mencapai kedalaman $60 \mathrm{~cm}$. Tujuan pembukaan sisi utara kotak S2T8 - S2T9 adalah untuk mengetahui kelanjutan struktur batu bata yang ditemukan di kotak S2T7. Pada kotak S2T8, yang dibuka dengan kedalaman $100 \mathrm{~cm}$ memiliki lapisan dengan warna hitam dan berukuran butir pasir sampai dengan kedalaman $80 \mathrm{~cm}$. Karena lapisan tersebut bercampur dengan temuan batu bata, maka tidak dapat dibedakan antara lapisan endapan pasir humus hitam, endapan pasir humus coklat, dan endapan pasir lepas coklat gelap. Sedangkan pada kedalaman di atas $80 \mathrm{~cm}$ lapisan sudah berganti dengan endapan pasir lepas kuning coklat dengan deskripsi sebagai berikut ukuran butir pasir, berwarna kuning kecoklatan. Sedangkan pada kotak S2T9 endapan pasir humus hitam, endapan pasir humus coklat, dan endapan pasir lepas coklat tidak dapat dibedakan karena sudah bercampur dengan temuan bata yang tidak semuanya utuh dan banyak yang hancur, sehingga bercampur dengan endapan yang menutupinya.

Kotak ekskavasi yang digunakan pada lintasan yang berarah utara - selatan yaitu lintasan U2T1 - S12T1. Lintasan tersebut berjumlah 10 (sepuluh) kotak dengan penyebutan sebagai berikut: kotak U2T1, U1T1, S3T1, S4T1, S5T1, S6T1, S7T1, S8T1, S11T1, dan S12T1 (Gambar 6).

Kotak U2T1 dibuka sampai dengan kedalaman $60 \mathrm{~cm}$. Tujuan pembukaan kotak adalah untuk mencari sudut bangunan pada sisi barat laut dan struktur bangunan. Pada permukaan tanahnya memiliki ukuran butir pasir yang berhumus, dengan warna abu-abu coklat gelap. Oleh karena lapisan tersebut bercampur dengan temuan batu bata, maka tidak dapat dibedakan antara lapisan endapan pasir humus hitam, endapan pasir humus coklat dan endapan pasir lepas coklat gelap.

Kotak U1T1 dibuka sampai dengan kedalaman $20 \mathrm{~cm}$, dikarenakan kotak ini sangat padat dengan temuan, maka tidak didalami lagi. Lapisan yang terdapat pada kotak U1T1 ini memiliki warna kecoklatan gelap dan berukuran pasir.

Kotak S3T1 dibuka sampai dengan kedalaman $130 \mathrm{~cm}$ dan berada tepat di samping kotak S3B1. Pembukaan kotak ini dilakukan atas dasar temuan struktur pondasi bangunan yang ada di kotak S3B1. Tampaknya struktur pondasi tersebut memanjang ke arah timur, karena pada kotak U1T2 sudah diketahui sudut pondasi bangunan tersebut. Pada kedalaman $60 \mathrm{~cm}$ terlihat lapisan berukuran butir pasir dengan warna hitam. Pada kedalaman $130 \mathrm{~cm}$ terdapat pondasi dengan lapisan berukuran butir pasir, berwarna kuning. Pada kotak S3T1 ini tidak dapat dibedakan antara lapisan endapan humus hitam, lapisan endapan humus coklat dan lapisan endapan pasir lepas coklat gelap.

Kotak S4T1 dibuka sampai dengan kedalaman $40 \mathrm{~cm}$. Pada prinsipnya, tujuan pembukaan kotak yang merupakan kelanjutan dari S5T1 - S5T2 ini adalah untuk menemukan struktur pondasi bangunan di sisi barat daya yang belum berhasil ditemukan di kotak tersebut. Lapisan pertama yang berada di bawah rumput berupa berupa tanah pasiran hitam dengan tekstur kasar dan lepas (tidak kompak) yang dalam skala Munsell berwarna Hue 2,5 Y 3/3 (dark olive brown). Lapisan kedua merupakan tanah yang agak padat.

Kotak S5T1 dibuka sampai dengan kedalaman $70 \mathrm{~cm}$. Tujuan penggalian kotak ini adalah untuk mencari struktur pondasi 
bangunan pada sisi barat daya. Kotak ini berada pada posisi miring atau melandai ke arah selatan. Jenis tanah pada kotak ini merupakan tanah hitam pasiran dengan tekstur kasar dan lepas-lepas, dengan warna tanah pada skala Munsell Hue 2,5 Y 3/3 (dark olive brown). Lapisan bagian bawahnya merupakan tanah padat bercampur bata merah.

Kotak S6T1 dibuka sampai dengan kedalaman $102 \mathrm{~cm}$. Kotak S6T1 dibuka dengan tujuan untuk mengetahui keberadaan bangunan lainnya di antara bangunan 1 dan bangunan 2. Titik yang diambil berdasarkan pembagian jarak yang sama antara bangunan 1 dan 2 sebagai patokan titik tengah bangunan ketiga serta kelurusan dengan penampil di bangunan 1 di sisi utara. Untuk memastikan pembukaan kotak ini mengenai struktur bata, maka kotak S6T1 dibuka membujur utara-selatan dengan ukuran sementara $1 \times 2 \mathrm{~m}$ pada sisi barat. Kondisi tanah di permukaan terlihat datar, dan terdapat beberapa bata yang terlihat muncul sedikit di permukaan tanah. Lapisan tanah mulai dari permukaan tanah sampai dengan kedalaman $10 \mathrm{~cm}$ merupakan tanah humus yang bercampur bata kecil-kecil dan tidak padat. Di lapisan tesebut merupakan lapisan tanah yang berwarna coklat. Pada kedalaman 20 $\mathrm{cm}$ kondisi dalam tanah menunjukkan perubahan dengan mulai ditemukannya bata berukuran besar dan berserakan dengan posisi yang sangat rapat sekali. Kondisi seperti ini masih berlangsung hingga pada lapisan tanah pasir yang berwarna hitam. Tanah ini sangat gembur, sifatnya lepas dengan butiran kasar, dan ketebalannya mencapai $20 \mathrm{~cm}$. Pada lapisan ini, kondisi bata di dekat dinding utara semakin jarang, sedangkan di sisi selatan tetap padat dan ukurannya pun besarbesar. Pada kedalaman $65 \mathrm{~cm}$ tanah berubah menjadi coklat kekuningan jenisnya pasir seperti pasir laut. Kondisi bata masih padat seperti lapisan sebelumnya dan mulai memperlihatkan indikasi adanya struktur. Hal ini dikarenakan posisi bata-bata banyak yang sedikit bergeser dari posisi seharusnya. Pada kedalaman $102 \mathrm{~cm}$ mulai terlihat adanya susunan bata yang masih insitu di sisi selatan.

Kotak S7T1 yang mencapai kedalaman $100 \mathrm{~cm}$ ini dibuka membujur arah utaraselatan pada sisi barat. Tujuannya untuk mendapatkan gambaran penampil sisi selatan sekaligus mengetahui lebar bangunan 2. Awal penggalian kotak di sisi selatan menunjukkan kepadatan tanah yang agak berbeda dengan permukaan sisi utara.

Kotak S8T1 dibuka sampai dengan kedalaman $60 \mathrm{~cm}$. Pembukaan kotak S8T1 bertujuan untuk mengetahui keberadaan struktur bangunan batu bata seperti kotak S2B1. Pembukaan kotak ini memakai teknik trench dengan ukuran $1 \times 4 \mathrm{~m}$, pada bagian selatan. Kotak S8T1 kondisi tanahnya dipenuhi remukan batu bata. Lapisan tanah berupa tanah berpasir warna kehitaman yang kondisinya gembur. Penggalian pada kotak ini diakhiri pada spit (3). Kondisi lapisan tanah pada spit (3) berupa pasir berwarna coklat terang dan keras.

Kotak S11T1 dibuka sampai dengan kedalaman $100 \mathrm{~cm}$. Alasan dibukanya kotak ini (Tim Penelitian 2010) adalah untuk mencari struktur bata dari bagian bangunan yang lain, yang diperkirakan bagian penampil atau bagian bangunan candi yang menjorok keluar sebagai tangga pintu masuk menuju ke dalam ruangan candi, dan bagian sudut. Kondisi permukaan kotak ini berupa sebaran bata dan tanaman rumput. Spit (1) digali hingga kedalaman $20 \mathrm{~cm}$ dari SDP (Secondary Datum Point). Lapisan tanah pada spit ini berupa tanah dengan warna kehitaman dan 
bercampur dengan kotoran hewan dan sudah teraduk. Banyak ditemukan sampah plastik dan juga beberapa fragmen bata. Spit (2) mulai digali pada kedalaman $20 \mathrm{~cm}$ hingga mencapai kedalaman $40 \mathrm{~cm}$. Lapisan tanah pada spit ini berupa pasir dengan warna kehitaman dengan temuan berupa fragmen bata dan fragmen keramik. Spit (3) digali pada kedalaman $40 \mathrm{~cm}$ sedalam $20 \mathrm{~cm}$ hingga mencapai kedalaman $60 \mathrm{~cm}$. Lapisan tanah pada spit ini berupa pasir dengan warna hitam pekat dengan temuan berupa fragmen keramik dan fragmen bata yang bertumpuk dengan jumlah yang sangat padat. Spit (4) digali pada kedalaman $60 \mathrm{~cm}$ hingga mencapai kedalaman $80 \mathrm{~cm}$. Spit (5) digali pada kedalaman $80 \mathrm{~cm}$ digali hingga mencapai kedalaman $100 \mathrm{~cm}$ dari permukaan tanah.

Kotak S12T1 dibuka sampai dengan kedalaman $80 \mathrm{~cm}$. Tujuan pembukaan kotak S12T1 (Tim Penelitian 2010) untuk mengetahui kelanjutan indikasi struktur bata yang telah ditemukan di kotak S12T2 pada kuadran Barat Laut yang diperkirakan berlanjut ke arah barat. Kondisi permukaan tanah kotak S12T1 sama dengan S12T2 karena letaknya berdampingan. Reruntuhan bata sudah mulai tampak sejak spit pertama, meskipun ukurannya kecil-kecil. Kondisi tanah permukaan hingga kedalaman $20 \mathrm{~cm}$ bersifat gembur, berpartikel kasar, berwarna coklat tua dan sudah teraduk dengan indikasi sampah masa kini. Pada kedalaman $20 \mathrm{~cm}$, reruntuhan bata masih terlihat padat meskipun tidak lagi merata di seluruh kotak dan menunjukkan ukuran yang lebih besar. Konsentrasi runtuhan bata terdapat pada bagian utara kotak dari timur ke barat. Tanah pada kedalaman ini berwarna coklat tua bercampur remukan bata dan akar kelapa. Setelah kedalaman $20 \mathrm{~cm}$, tanah berubah warna menjadi kehitaman dengan tekstur halus bercampur pasir. Tanah jenis ini mempunyai ketebalan $40 \mathrm{~cm}$ dan merata di seluruh kotak. Sifat tanah ini tidak rapat, sehingga memudahkan air menembus dan mengakibatkan longsor. Pengupasan dilanjutkan hingga kedalaman $80 \mathrm{~cm}$ untuk mengetahui apakah masih ada runtuhan bata yang terpendam. Hasil ekskavasi pada kotak S12T1 pada kedalaman $80 \mathrm{~cm}$ sudah steril sehingga penggalian dihentikan, apalagi sumber air mulai keluar dengan deras.

Berdasarkan deskripsi masing-masing lapisan kotak ekskavasi yang dijadikan lintasan stratigrafi di atas, maka secara garis besar urutan stratigrafi di lokasi penelitian dari atas ke bawah meliputi:

(1). Lapisan endapan pasir humus hitam

Endapan pasir humus hitam memiliki deskripsi umum sebagai berikut, warna abuabu kehitaman atau dalam skala Munsell 3/1 very dark grey 7,5 yr; berukuran butir antara pasir kasar sampai dengan lanau; pada lapisan ini terdapat banyak akar; struktur sedimen tidak tampak pada lapisan ini; sortasi lapisan cukup bagus; bentuk butir agak membulat; dan ketebalan lapisan bervariasi antara $20-25 \mathrm{~cm}$.

(2). Lapisan endapan pasir humus coklat

Endapan pasir humus coklat ini memiliki deskripsi umum sebagai berikut, warna $3 / 4$ dark brown 7,5 yr (dalam skala Munsell); berukuran butir pasir kasar sampai dengan lempung; struktur sedimen tidak tampak pada lapisan ini; pada lapisan ini di beberapa tempat masih terlihat akar; sortasi lapisan agak buruk; bentuk butir agak membulat; dan ketebalan lapisan bervariasi antara $15-27 \mathrm{~cm}$.

(3). Lapisan endapan pasir lepas coklat gelap Memiliki deskripsi umum sebagai berikut, warna $3 / 3$ very dark brown $7,5 \mathrm{yr}$ (dalam skala Munsell); ukuran butir pasir kasar sampai 
dengan pasir halus; struktur tidak tampak; terkadang masih terlihat akar pada beberapa tempat; sortasi sedang sampai bagus; kemas tertutup; bentuk butir membulat; dan ketebalan lapisan bervariasi antara $20-31$ $\mathrm{cm}$.

(4). Lapisan endapan pasir lepas kuning coklat

Memiliki deskripsi umum sebagai berikut warna 4/6 dark yellowish brown 10 yr (dalam skala Munsell); ukuran butir pasir sangat kasar sampai pasir sedang; struktur tidak tampak; sortasi bagus; kemas terbuka; bentuk butir agak meruncing; dan ketebalan lapisan bervariasi antara $30-39 \mathrm{~cm}$.

Stratigrafi di lokasi penelitian ini, apabila dikorelasikan dengan stratigrafi regional (Keyser dan Rustandi 1993) termasuk dalam endapan aluvium dan endapan rawa yang terdiri atas kerikil, pasir, lanau, lumpur, gambut, dan bongkah yang tak terpisahkan.

\section{Analisis Lingkungan Pengendapan}

Stratigrafi lengkap Situs Negeri Baru dari bawah ke atas lapisan terbawah adalah sebagai berikut: lapisan endapan pasir lepas kuning coklat yang di atasnya ditutupi oleh lapisan endapan pasir lepas coklat gelap; lapisan endapan pasir humus coklat; dan terakhir pada lapisan paling atas adalah lapisan endapan pasir humus hitam (Gambar 7).

Lapisan pertama, yaitu lapisan endapan pasir humus hitam. Lapisan ini memiliki deskripsi umum sebagai berikut: warna abuabu kehitaman atau dalam skala Munsell 3/1 very dark grey 7,5 yr; berukuran butir antara pasir kasar sampai dengan lanau; pada lapisan ini terdapat banyak akar; struktur sedimen tidak tampak pada lapisan ini; sortasi lapisan cukup bagus; bentuk butir agak membulat; dan ketebalan lapisan bervariasi antara 20 - $25 \mathrm{~cm}$. Berdasarkan kenampakan fisiknya kemungkinan lingkungan pengendapan dari lapisan ini adalah sol atau tanah.

Lapisan kedua, yaitu lapisan endapan pasir humus coklat. Lapisan ini memiliki deskripsi umum sebagai berikut: warna $3 / 4$ dark brown 7,5 yr (dalam skala Munsell); berukuran butir pasir kasar sampai dengan lempung; struktur sedimen tidak tampak pada lapisan ini; pada lapisan ini di beberapa tempat masih terlihat akar; sortasi lapisan agak buruk; bentuk butir agak membulat; dan ketebalan lapisan bervariasi antara $15-27 \mathrm{~cm}$. Berdasarkan kenampakan fisiknya, kemungkinan lingkungan pengendapan dari lapisan ini adalah sol atau tanah.

Lapisan ketiga, yaitu lapisan endapan pasir lepas coklat gelap. Lapisan ini memiliki deskripsi umum sebagai berikut: warna $3 / 3$ very dark brown 7,5 yr (dalam skala Munsell); ukuran butir pasir kasar sampai dengan pasir halus; struktur tidak tampak; sortasi sedang sampai bagus; kemas tertutup; bentuk butir membulat; dan ketebalan lapisan bervariasi antara $20-31 \mathrm{~cm}$. Berdasarkan kenampakan fisiknya kemungkinan lingkungan pengendapan dari lapisan ini adalah estuari atas, bay head delta channels.

Lapisan keempat, yaitu lapisan endapan pasir lepas kuning coklat. Lapisan ini memiliki deskripsi umum sebagai berikut warna 4/6 dark yellowish brown $10 \mathrm{yr}$ (dalam skala Munsell); ukuran butir pasir sangat kasar sampai pasir sedang; struktur tidak tampak; sortasi bagus; kemas terbuka; bentuk butir agak meruncing; dan ketebalan lapisan bervariasi antara $30-39 \mathrm{~cm}$. Kemungkinan lingkungan pengendapan dari lapisan ini 


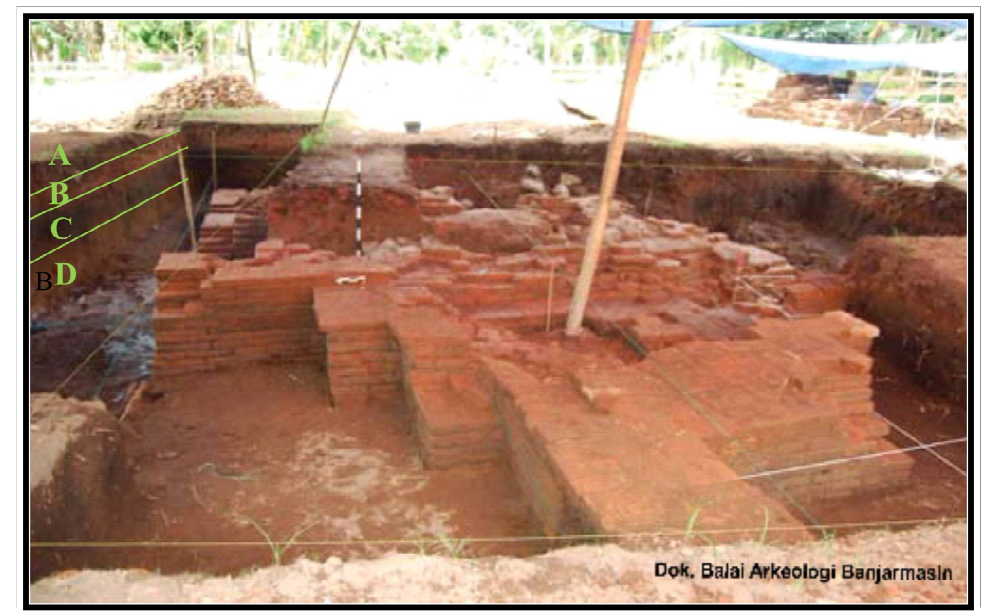

Gambar 7. Penampang stratigrafi Situs Negeri Baru, Ketapang, Kalimantan Barat: A adalah pasir humus hitam; $B$ adalah pasir humus coklat; $C$ adalah pasir lepas coklat gelap; $D$ adalah pasir lepas kuning coklat (dok. Balai Arkeologi Banjarmasin 2010)

adalah permukaan pantai bagian atas (upper shoreface), yaitu pada mulut estuari (estuary mouth).

Lingkungan pengendapan pada Situs Negeri Baru yang terlihat pada Gambar 7 memperlihatkan perubahan dari bawah ke atas, yaitu permukaan pantai atas (upper shoreface) menjadi estuari atas kemudian menjadi tanah (sol). Pada fasies pengendapan dalam Buatois dkk (1999) terjadi perubahan dari fasies I menjadi fasies $C$ kemudian fasies $B$.

Ekskavasi Situs Negeri Baru dilakukan pertama kali oleh Balai Arkeologi Banjarmasin pada tahun 2007. Hasil yang didapatkan adalah temuan baru yang belum pernah ada di Kalimantan Barat. Temuan tersebut adalah susunan bata kuna yang diduga sebagai reruntuhan bangunan candi. Susunan bata tersebut disertai dengan beberapa temuan lain yang diduga berkaitan dengan eksistensi bangunan tersebut di masa lalu. Sisa struktur bangunannya berupa susunan bata tiga lapis pada posisi miring akibat roboh, sedangkan pondasinya berupa batu alam. Sebaran keramik yang terdapat di sekitar bangunan memberikan sedikit petunjuk tentang pemanfaatan bangunan pada masa lalu.

Proses sedimentasi di Situs Negeri Baru ini diawali dengan pengendapan pasir sangat kasar sampai pasir sedang yang diikuti perkembangan dari struktur silang siur. Pada bagian atasnya adalah lapisan yang sangat kaya dengan cangkang dan pecahannya. Lapisan ini terdapat pada fasies I dengan lingkungan pengendapan upper shoreface. Proses berikutnya pengendapan langsung berubah menjadi pasir kasar sampai halus dengan warna coklat gelap setempat terdapat lanau (clay drapes). Lapisan ini merupakan fasies $C$ dengan lingkungan pengendapan estuari atas, bay head delta channels. Kemudian yang terakhir adalah pengendapan pasir coklat dan pasir hitam yang berukuran 
pasir kasar sampai lempung yang merupakan proses pedogenik sehingga pada fasies ini banyak terdapat akar. Lingkungan pengendapan fasies ini adalah paleosols yang terdapat di tepi fluvial channels.

Berdasarkan uraian di atas, terlihat bahwa lingkungan pengendapan pada Situs Negeri Baru berubah dari lingkungan pantai yaitu permukaan pantai bagian atas (upper shoreface) menjadi lingkungan sungai (upper estuary, bay head delta channels) kemudian darat yaitu paleosol yang terletak di tepi aliran sungai (fluvial channels). Jika dilihat berdasarkan skema pada gambar 5 , maka terdapat perubahan lingkungan yang tidak menerus dalam urutan stratigrafi. Hal tersebut disebabkan lapisan endapan pasir lepas kuning coklat yang memiliki lingkungan pengendapan pada fasies I dalam skema tersebut. Sedangkan lapisan endapan pasir lepas coklat gelap memiliki lingkungan pengendapan pada fasies $C$, kemudian lapisan endapan pasir humus coklat dan lapisan endapan pasir humus hitam memiliki lingkungan pengendapan pada fasies $\mathrm{B}$. Hal ini mungkin disebabkan oleh penurunan muka air laut yang cukup cepat, sehingga fasies di antara I dan C tidak terbentuk pada selang waktu di antara pengendapan tersebut.

\section{Kesimpulan}

1. Stratigrafi yang terdapat pada lokasi Situs Negeri Baru terdiri atas empat lapisan, yaitu (dari bawah ke atas) lapisan endapan pasir lepas kuning coklat; lapisan endapan pasir lepas coklat gelap; lapisan endapan pasir humus coklat; dan lapisan teratas adalah lapisan endapan pasir humus hitam.

2. Lapisan tersebut masing-masing memiliki tiga macam fasies yaitu fasies I, fasies $C$, dan fasies $B$.

3. Dari bawah ke atas, perubahan lingkungan pengendapan kemungkinan disebabkan oleh lingkungan pengendapan yang berubah ke arah darat, sehingga situs yang semula berada di tepi pantai (upper shoreface), pada saat ini berada di estuari atas dan tepi sungai (sol) kurang lebih jauhnya $20 \mathrm{~km}$ dari pantai. Hal ini disebabkan turunnya permukaan air laut dengan cepat, sehingga fasies di antara I dan C tidak terbentuk. 
Lingkungan Pengendapan di Situs Negeri Baru, Kalimantan Barat 26-43

\section{Referensi}

Buatois, L.A., Mangano G, dan Carr T. R. 1999. Sedimentology and ichnology of Paleozoic estuarine and shoreface reservoirs, morrow sandstone, lower Pennsylvanian of Southwest Kansas, USA. Kansas geological survey. Current Research in Earth Sciences Bulletin 243: 1-14, diunduh dari http:/ /www.kgs.ku.edu/Current/1999/ buatois/buatois2.html, 1 Maret 2012

de Keyser, F. dan Rustandi E. 1993. Peta Geologi Lembar Ketapang, Kalimantan skala 250.000. Bandung: Pusat Penelitian dan Pengembangan Geologi
Mochtar, Herman. 2007. Evolusi pengendapan sedimen Kuarter di daerah utara Air Musi, Kota Palembang - Sumatera Selatan. Jurnal Geologi Indonesia 2 (1): 1 13.

Tim Penelitian. 2010. Ekskavasi Situs Negeri Baru, Kabupaten Ketapang, Kalimantan Barat, Banjarmasin. Laporan Penelitian Arkeologi Balai Arkeologi Banjarmasin. Banjarbaru: Balai Arkeologi Banjarmasin. Belum diterbitkan. 